\title{
Mast Cells in Mammary Carcinogenesis: Host or Tumor Supporters?
}

\author{
ANA I. FAUSTINO-ROCHA ${ }^{1,2,3,4}$, ADELINA GAMA ${ }^{1,3}$, MARIA J. NEUPARTH ${ }^{5,6}$, \\ PAULA A. OLIVEIRA ${ }^{1,2}$, RITA FERREIRA $^{4}$ and MÁRIO GINJA ${ }^{1,2}$ \\ ${ }^{1}$ Department of Veterinary Sciences and ${ }^{3}$ Animal and Veterinary Research Center (CECAV), \\ School of Agrarian and Veterinary Sciences, and ${ }^{2}$ Center for the Research and Technology of Agro-Environmental \\ and Biological Sciences (CITAB), University of Trás-os-Montes and Alto Douro, Vila Real, Portugal; \\ ${ }^{4}$ Organic Chemistry, Natural Products and Foodstuffs (QOPNA), Mass Spectrometry Center, \\ Department of Chemistry, University of Aveiro, Aveiro, Portugal; \\ ${ }^{5}$ Advanced Polytechnic and University Cooperative (CESPU), \\ Institute of Research and Advanced Training in Health Sciences and Technologies (IINFACTS), Gandra, Portugal; \\ ${ }^{6}$ Research Center in Physical Activity, Health and Leisure (CIAFEL), \\ Faculty of Sports, University of Porto, Porto, Portugal
}

\begin{abstract}
Background/Aim: The effects of mast cells on carcinogenesis is not yet fully understood. This work aimed to disclose the role of mast cells in mammary carcinogenesis in a rat model. Materials and Methods: Mammary tumors were induced by the administration of $\mathrm{N}$-methyl-N-nitrosourea (MNU) in three groups of rats. Animals from one group were treated with ketotifen immediately after MNU administration, and animals from another only received ketotifen after the development of the first mammary tumor. The biochemical profile was determined. Mammary tumors were evaluated by histopathology and immunohistochemistry. Results: Animals from ketotifen-treated groups developed fewer mammary tumors, higher number of mammary lesions and had lower histamine levels when compared to non-treated animals. Animals treated with ketotifen immediately after MNU exhibited the lowest proliferative and apoptotic indexes. Conclusion: The mainly positive effect of the inhibition of mast cell degranulation seems to be the reduction of tumor proliferation when the mast cell degranulation was inhibited before tumor development.
\end{abstract}

Cancer is a multistage process that involves complex interactions between malignant and non-malignant cells.

This article is freely accessible online.

Correspondence to: Ana I. Faustino, CITAB, Department of Veterinary Sciences, University of Trás-os-Montes and Alto Douro, 5001-911, Vila Real, Portugal. E-mail: anafaustino.faustino@sapo.pt

Key Words: Degranulation, ketotifen, mammary tumors, mast cells, MNU, rat.
Lymphatic and vascular endothelial cells, pericytes, adipocytes, mesenchymal stem cells, smooth muscle cells, fibroblasts, myofibroblasts, myeloid cells and inflammatory cells (B- and T-lymphocytes, neutrophils, dendritic cells, eosinophils, basophils, natural killer cells, macrophages and mast cells) are among the non-malignant cells that constitute the tumor microenvironment (1).

Mast cells are ovoid or elongated granular cells that arise from the multipotent precursor $\mathrm{CD}_{3} 4^{+}$in the bone marrow (2). They are complex, well-engineered and multifunctional cells that play an important role in innate and acquired immunity (3, 4). Although mast cells were first described by Paul Ehrlich as a normal component of connective tissue (5), nowadays it is known that they are physiologically present in several tissues, especially where the body interacts with the environment (skin, respiratory tract, gastrointestinal tract, mucosal surfaces and connective tissue) (6). They may also be occasionally seen in the bone marrow but almost never in circulation (7).

Over the years, mast cells have interested the scientific community and their role has been studied in several conditions, namely dermatitis, bullous pemphigoid, fibrotic lung disease, psoriasis, rheumatoid arthritis, Crohn's disease, ulcerative colitis, interstitial cystitis, asthma, allergic rhinitis, sinusitis and cancer (skin, breast, lung, kidney, stomach, melanoma and multiple myeloma) $(8,9)$. Mast cells have several bioactive substances with pro-apoptotic and antiapoptotic activity in their cytoplasmic granules. In the specific case of cancer, histamine, tryptase and chymase promote tumor angiogenesis, proliferation and metastasis; while heparin, interleukin (IL)-1, IL21 and tumor necrosis factor inhibit tumor growth (10-13). The association between the presence of mast cells and the conversion of premalignant to 
malignant lesions in a rat model of chemically induced skin and mammary tumors was reported (14), as well as the correlation of the mast cell number in breast cancer with tumor aggressiveness and poor prognosis in human (15) and canine mammary tumors (16). Hence the idea that mast cells are correlated with tumor progression arises and that inhibition of their degranulation may suppress mammary tumor growth.

Ketotifen is a benzocycloheptathiophene compound that at low concentrations exerts antihistaminic activity (it is a second-generation histamine 1 receptor antagonist) (17). Additionally, ketotifen blocks calcium channels essential for mast cell degranulation, stabilizing their membranes and consequently inhibiting their degranulation $(18,19)$.

As breast cancer remains a leading cancer type among women worldwide (20), this study aimed to clarify the role of mast cells in mammary carcinogenesis, through the inhibition of mast cell degranulation by an antihistamine drug in a recognized rat model of MNU-induced mammary cancer.

\section{Materials and Methods}

Animals. Thirty-four female Sprague-Dawley rats of 4 weeks of age were used (Harlan Interfauna, Barcelona, Spain). Animals were placed in the facilities of the University of Trás-os-Montes and Alto Douro (UTAD) under controlled conditions of temperature $\left(23 \pm 2^{\circ} \mathrm{C}\right)$, humidity $(50 \pm 10 \%)$, air system filtration $(10-20$ ventilations/hour) and on a 12:12-hour light:dark cycle. Animals were fed with a standard laboratory diet (4RF21; Mucedola, Settimo Milanese MI, Italy) and tap water ad libitum. All procedures followed the European and National legislation on the protection of animals used for scientific purposes (European Directive 2010/63/EU and National Decree-Law 113/2013). The experimental protocol was approved by the Ethics Committee of UTAD (CE_122013) and by the Portuguese Ethics Committee for Animal Experimentation (approval no. 008961).

Experimental protocol. After 1 week of quarantine and 2 weeks of acclimatization to the laboratory conditions, animals were randomly divided into five experimental groups as follows: group I: $N$-methyl$N$-nitrosourea (MNU); $\mathrm{n}=10$, group II: MNU plus ketotifen-1; $\mathrm{n}=10$, group III: MNU plus ketotifen-2; $n=10$, group IV: ketotifen; $n=2$ and group V: control; $n=2$. At 7 weeks of age, all animals from groups I, II and III received an intraperitoneal injection of MNU (Isopac ${ }^{\circledR}$; Sigma Chemical Co., Madrid, Spain) at a dose of 50 $\mathrm{mg} / \mathrm{kg}$. Animals from groups IV and $\mathrm{V}$ received a single intraperitoneal injection of the vehicle (saline solution $0.9 \%$ ). These control groups were used in order to ensure that no histological alterations occurred due to the experimental procedures, namely the ketotifen administration. The first day of the experimental protocol was defined as the day of the MNU administration. On the day after the MNU or saline administration, animals from groups II and IV received mast cell stabilizer ketotifen (Zaditen ${ }^{\circledR}$, Defiante Farmacêutica S.A., Portugal) in drinking water, at a concentration of $1 \mathrm{mg} / \mathrm{kg}, 7$ days/week for 18 weeks. Each animal from group III only received ketotifen after the development of the first mammary tumor. Animals from groups I and $\mathrm{V}$ received only water during the protocol (Figure 1).
Animals were observed twice a day throughout the experiment in order to monitor their health status during the experiment. Mammary chains from all animals were palpated once a week to detect the development of mammary tumors. Food and water consumption and animal body weight were measured weekly using a top-loading scale (METTLER ${ }^{\circledR}$ PM 4000; LabWrench, Midland, Canada). At the end of the experiment, body weight gain and mortality index were calculated $(21,22)$.

Sample collection. At the seventh week after MNU administration, blood samples were collected from the tail vein directly into capillary tubes; the samples were centrifuged and the serum was stored at $-80^{\circ} \mathrm{C}$ to determine the histamine level. Immediately before animal sacrifice, urine samples were collected using metabolic cages, the samples were centrifuged and the specific gravity of urine was determined using a refractometer (Atago Co., Tokyo, Japan).

Sacrifice. Eighteen weeks after the MNU administration (animals of 25 weeks of age), all surviving animals were humanely sacrificed by intraperitoneal injection of ketamine $(75 \mathrm{mg} / \mathrm{kg}$ Imalgene 1000 ; Merial S.A.S., Lyon, France) and xylazine (10 mg/kg, Rompun 2\%; Bayer Healthcare S.A., Kiel, Germany), followed by exsanguination by cardiac puncture as indicated by the Federation for Laboratory Animal Science Associations (23). At that time, blood samples were collected from the inferior vena cava directly into capillary tubes and tubes with separator gel. The tubes were centrifuged for $5 \mathrm{~min}$ at $5,000 \times g$, the serum was obtained and stored at $-80^{\circ} \mathrm{C}$ for biochemical determinations.

Animals were scalped and the skin was carefully evaluated under a light in order to detect mammary tumors not previously identified by palpation. Mammary tumors were removed, weighed and the tumor volumes determined based on their weight (22). Accurate animal body weight was obtained by the subtraction of tumor weight from the final body weight. All tumors and organs were collected, weighed and immersed in formalin for $24 \mathrm{~h}$.

Blood samples analysis. Hematocrit was determined immediately after the centrifugation of the capillary tubes. Serum levels of histamine were determined using a commercial Enzyme-Linked Immunosorbent Assay (ELISA) kit (MBS494164, MyBioSource, San Diego, CA, USA) according to the manufacturer's instructions. Serum albumin, total protein, cholesterol, glucose, triglycerides, creatinine, alanine aminotransferase (ALT), creatine kinase, lactate dehydrogenase and lactate were measured in duplicate on an AutoAnalyzer (PRESTIGE 24i; Cormay PZ, Holliston, MA, USA). C-Reactive protein (CRP) was determined by immunoblotting using a rabbit monoclonal antibody to CRP (ab32412; Abcam, Cambridge, UK).

Histology and immunohistochemistry. After fixation, mammary tumors were cut, included in paraffin and processed for routine histological evaluation. Two $\mu \mathrm{m}$-thick sections were stained with hematoxylin and eosin (H\&E). Mammary tumors were histologically evaluated under light microscopy by a pathologist and classified according to Russo and Russo (24). To determine mast cell density, a section from each mammary tumor was stained with toluidine blue. Mast cells were counted in 15 amplified fields (magnification of $\times 400)$ in each section and the mean number was determined (25).

The expression of $\mathrm{Ki}-67$, and cleaved caspases -3 and -9 in each mammary lesion was evaluated by immunohistochemistry. For this purpose, the standard protocol of NovoLink Polymer Detection 


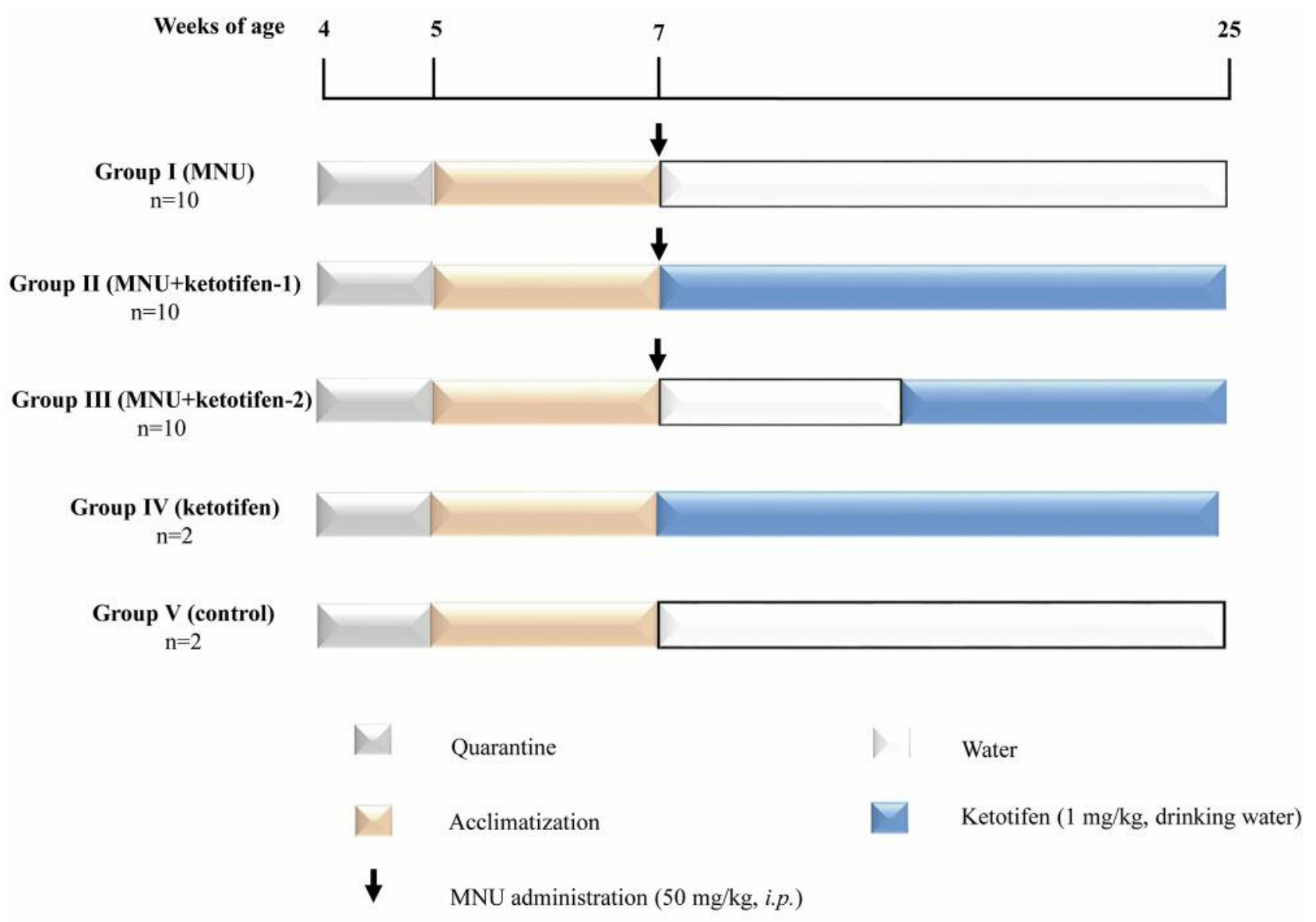

Figure 1. Schematic representation of the experimental protocol. MNU: N-methyl-N-nitrosourea; i.p.: intraperitoneal administration.

System (Leica Biosystems, Newcastle, UK) was used. Sections were incubated with primary antibodies for Ki-67 (clone MIB-5; Dako, Glostrup, Denmark), caspase-3 (clone Asp 175; Cell Signaling Technology, Danvers, MA, USA) and caspase-9 (Asp 353; Cell Signaling Technology) at a dilution of $1: 50$ overnight at $4^{\circ} \mathrm{C}$. The immunoexpression of all markers was evaluated as the percentage of stained cells in a total of at least 1000 neoplastic cells.

Statistical analysis. Data were statistically analyzed using SPSS ${ }^{\circledR}$ version 23 (IBM Corp., Armonk, NY, USA). Continuous data were compared among groups using analysis of variance (ANOVA). Histological results were analyzed using chi-square tests. Continuous data are expressed as mean \pm standard error (S.E.); $p$ values lower than 0.05 were considered statistically significant.

\section{Results}

General data. One animal from group II (mortality index of $10 \%$ ) died during the experiment. Data from this animal were not included in the study. Statistically significant differences were not found in food and water consumption (data not shown), nor in animal body weight, ponderal gain and organ weight among groups $(p>0.05)$. Although the differences did not reach the level of statistical significance, final body weight was slightly lower in ketotifen-treated animals previously exposed to MNU (groups II and III) when compared with the remaining groups (Tables I and II).

Mammary tumors. As expected, animals from groups IV and $\mathrm{V}$ did not develop any mammary tumor. The first mammary tumors were simultaneously identified in all MNU-exposed groups (groups I, II and III) 8 weeks after MNU administration (Figure 2).

An incidence of $60 \%(6 / 10)$ in group I, $89 \%(8 / 9)$ in group II and $70 \%(7 / 10)$ in group III was observed at the end of the experimental protocol. As the aim of the study was to evaluate the effects of mast cells on mammary tumorigenesis, we only considered the data from animals that actually developed mammary tumors. A total of 58 mammary tumors were counted at the end of the experiment: 21 tumors in group I (3.5 tumors per animal), 19 tumors in group II (2.4 tumors per animal) and 18 tumors in group III (2.6 tumors per animal) 
Table I. Initial and final accurate body weight $(\mathrm{g})$, ponderal gain (\%), and mammary tumor volume and weight in all experimental groups (mean \pm S.E.).

\begin{tabular}{|c|c|c|c|c|c|c|}
\hline \multirow[t]{2}{*}{ Group } & \multirow[t]{2}{*}{$\mathrm{n}$} & \multicolumn{2}{|c|}{ Accurate body weight $(\mathrm{g})$} & \multirow[t]{2}{*}{ Ponderal gain $(\%)$} & \multicolumn{2}{|c|}{ Mammary tumors } \\
\hline & & Initial & Final & & Weight $(\mathrm{g})$ & Volume $\left(\mathrm{cm}^{3}\right)$ \\
\hline $\mathrm{I}(\mathrm{MNU})$ & 6 & $188.27 \pm 3.78$ & $304.78 \pm 8.54$ & $38.10 \pm 1.27$ & $3.24 \pm 0.66$ & $3.08 \pm 0.63$ \\
\hline II (MNU + ketotifen-1) & 8 & $178.40 \pm 3.26$ & $272.78 \pm 11.35$ & $33.75 \pm 3.09$ & $5.40 \pm 1.40$ & $5.11 \pm 1.32$ \\
\hline III (MNU + ketotifen-2) & 7 & $187.69 \pm 4.88$ & $286.44 \pm 6.72$ & $34.39 \pm 1.46$ & $2.62 \pm 0.74$ & $2.48 \pm 0.70$ \\
\hline IV (Ketotifen) & 2 & $198.22 \pm 12.70$ & $304.20 \pm 18.00$ & $34.86 \pm 0.32$ & - & - \\
\hline V (Control) & 2 & $183.82 \pm 2.84$ & $295.98 \pm 9.78$ & $37.86 \pm 1.10$ & - & - \\
\hline
\end{tabular}

MNU: $N$-Methyl- $N$-nitrosourea. Statistically significant differences were not found $(p>0.05)$.

Table II. Absolute organ weight $(g)$ in all study groups (mean \pm S.E.).

\begin{tabular}{|c|c|c|c|c|c|c|c|}
\hline Group & $\mathrm{n}$ & Heart & Lung & Spleen & Liver & Left kidney & Right kidney \\
\hline I (MNU) & 6 & $1.15 \pm 0.08$ & $1.74 \pm 0.09$ & $0.99 \pm 0.10$ & $9.18 \pm 1.01$ & $1.16 \pm 0.03$ & $1.21 \pm 0.03$ \\
\hline II (MNU + ketotifen-1) & 8 & $1.17 \pm 0.09$ & $1.62 \pm 0.06$ & $1.20 \pm 0.14$ & $9.37 \pm 0.55$ & $1.16 \pm 0.06$ & $1.21 \pm 0.03$ \\
\hline III (MNU + ketotifen-2) & 7 & $1.13 \pm 0.03$ & $1.65 \pm 0.05$ & $2.03 \pm 0.96$ & $9.78 \pm 0.35$ & $1.28 \pm 0.06$ & $1.30 \pm 0.03$ \\
\hline IV (Ketotifen) & 2 & $1.12 \pm 0.04$ & $1.76 \pm 0.01$ & $0.78 \pm 0.08$ & $8.13 \pm 0.53$ & $1.27 \pm 0.14$ & $1.30 \pm 0.11$ \\
\hline V (Control) & 2 & $1.13 \pm 0.07$ & $1.95 \pm 0.19$ & $0.89 \pm 0.13$ & $9.04 \pm 0.51$ & $1.20 \pm 0.03$ & $1.20 \pm 0.00$ \\
\hline
\end{tabular}

MNU: $N$-Methyl- $N$-nitrosourea. Statistically significant differences were not found $(p>0.05)$.

(Figure 2). The number of mammary tumors was not statistically different among groups $(p>0.05)$. Although the mammary tumor volume and weight were higher in animals that received ketotifen immediately after MNU administration (group II) when compared with non-treated animals (group I) and animals that only received ketotifen after tumor development (group III), the differences among groups did not reach the level of statistical significance $(p>0.05)$ (Table I).

Blood and urine samples analysis. The serum level of histamine was measured before (at the seventh week of the experiment) and after the development of mammary tumors (at the 18th week of the experiment) in all experimental groups. The serum histamine level increased between the seventh and the last week of the experimental protocol $(p>0.05)$. Among the animals that developed mammary tumors, the animals from group II (MNU plus ketotifen-1) exhibited the lowest serum histamine levels followed by animals from group III (MNU plus ketotifen-2) (Table III). The majority of the biochemical parameters were similar among groups $(p>0.05)$ (Table IV).

Histological analysis. Histologically, it was verified that mammary tumors exhibited more than one mammary lesion. In this way, 35 mammary lesions in group I (MNU), 44 mammary lesions in group II (MNU plus ketotifen-1) and 48 mammary lesions in group III (MNU plus ketotifen-2) were
Table III. Serum histamine levels $(\mathrm{ng} / \mathrm{ml})$ in all groups before tumor development and at the end of the experimental protocol (mean \pm S.E.).

\begin{tabular}{lccc}
\hline Group & $\mathrm{n}$ & \multicolumn{2}{c}{ Serum histamine levels (ng/ml) } \\
\cline { 2 - 4 } & & $\begin{array}{c}7 \text { Weeks } \\
\text { after MNU }\end{array}$ & $\begin{array}{c}18 \text { Weeks } \\
\text { after MNU }\end{array}$ \\
\hline I (MNU) & 6 & $45.46 \pm 5.52$ & $109.55 \pm 31.22$ \\
II (MNU + ketotifen-1) & 8 & $46.53 \pm 3.19$ & $91.16 \pm 32.84$ \\
III (MNU + ketotifen-2) & 7 & $44.80 \pm 5.42$ & $100.47 \pm 50.24$
\end{tabular}

MNU: $N$-Methyl- $N$-nitrosourea. Statistically significant differences were not found $(p<0.05)$.

identified. The highest number of benign mammary lesions was identified in group III (statistically higher than in group I, $p<0.05$ ), while the highest number of malignant lesions was observed in group II. No pre-neoplastic lesions were identified in groups I and II. Papillary non-invasive carcinoma was the malignant lesion most frequently identified in all groups. The number of cribriform noninvasive carcinomas was higher in groups II and III when compared with group I $(p<0.05)$ (Table V).

Mast cells appeared as granular mononuclear cells in all mammary tumors. The toluidine blue stained their granules purple in color. The majority of mast cells were observed 


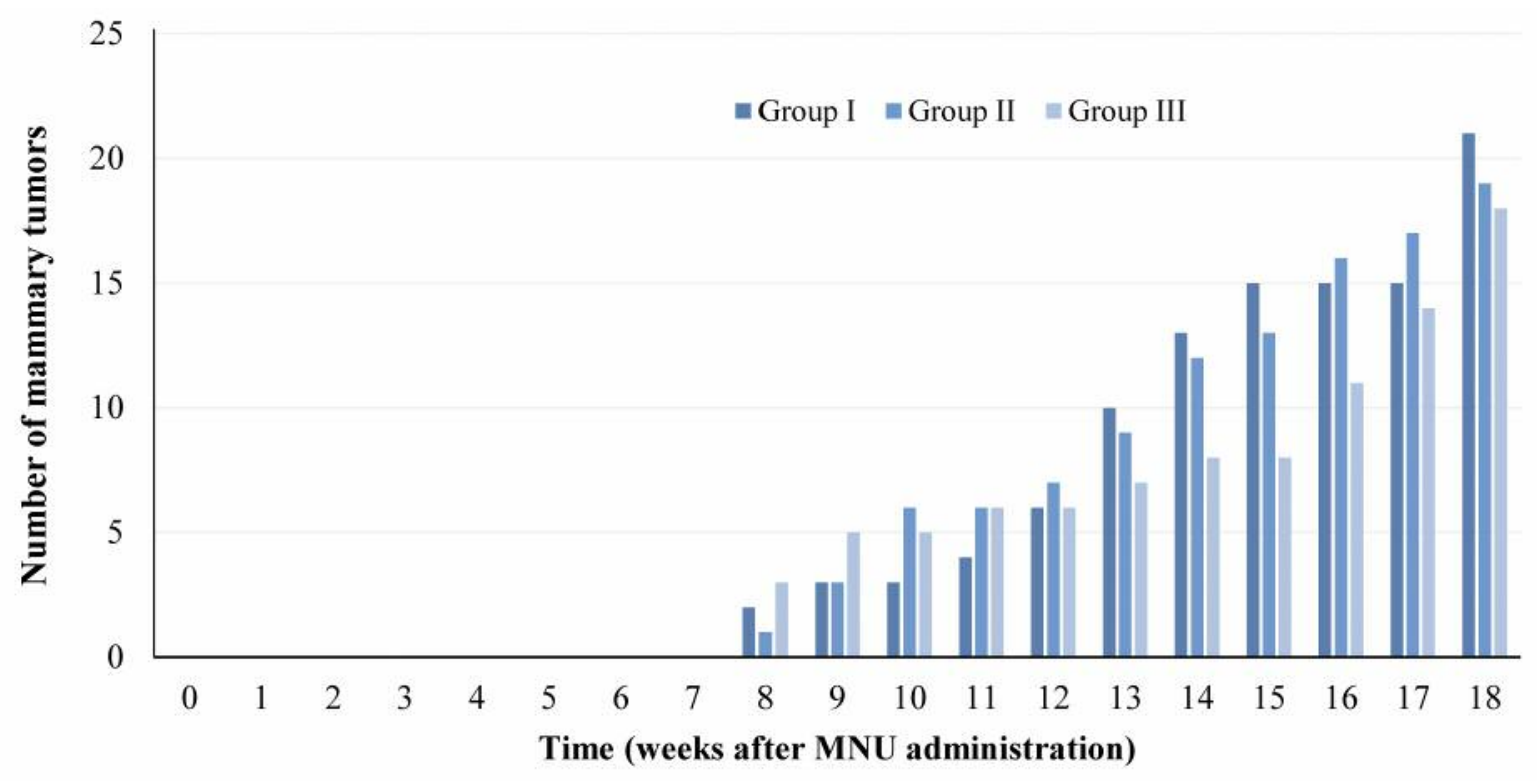

Figure 2. Graphic representation of the number of mammary tumors in groups I, II and III and the respective week of their appearance (p $>0.05$ ).

in the connective tissue around the tumor and were lower in number in the tumor core (Figure 3A). The mean number of mast cells was higher in mammary tumors when compared with normal mammary gland $(p<0.05)$. Additionally, the mean number of mast cells was higher in group II (MNU plus ketotifen-1) when compared with groups I (MNU) and III (MNU plus ketotifen-2) $(p<0.05)$ (Figure 4).

Immunohistochemistry. The proliferative index was higher in groups I (MNU) and III (MNU plus ketotifen-2) when compared with group II (MNU plus ketotifen-1) $(p<0.05)$. In the same way, the apoptotic index as evaluated by the immunoexpression of caspase- 3 and -9 was higher in groups I and III, when compared with group II (statistically significant differences were not observed, $p>0.05$ ) (Table VI, Figure 3B-D).

\section{Discussion}

In 2012, cancer was responsible for approximately 8.2 million deaths around the world (26). In this way, it is one of the diseases most feared by humans and a disease of a great concern among the scientific community. As an attempt to find new preventative and therapeutic strategies, persistent research, mainly using animal models such as rats and mice, has been performed in this field.

After several years studying carcinogenesis in distinct organs, such as urinary bladder, liver, skin, and more recently mammary gland, our research team observed a

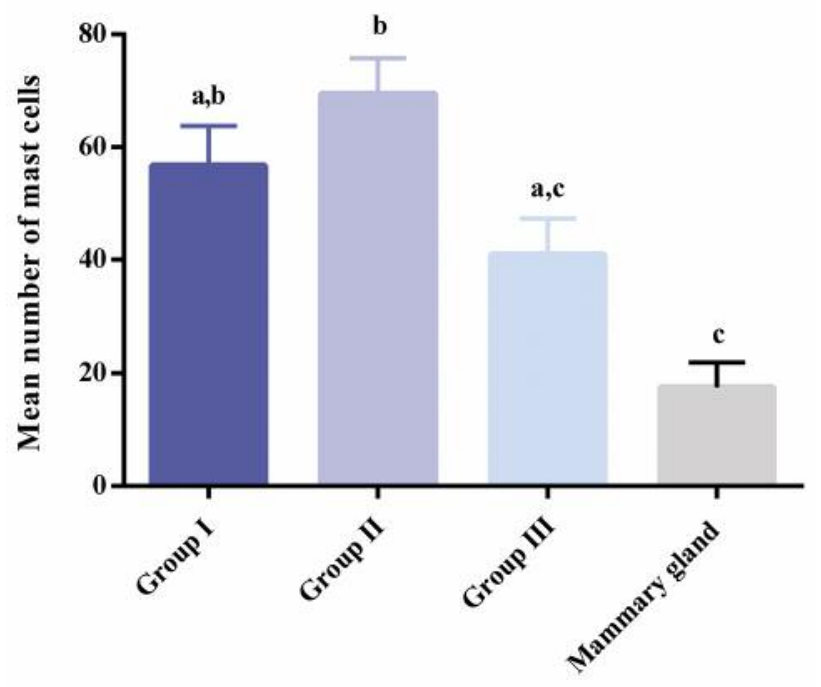

Figure 3. Mean number of mast cells in mammary tumors from animals that received the carcinogen $N$-methyl-N-nitrosourea and in the normal mammary gland. Values with different letters are statistically different $(p<0.05)$.

marked infiltration of mast cells in these types of cancer. The question therefore arose of what is the role of mast cells in cancer? Do they favor tumor progression or do they help the host against the neoplasia? Indeed, the existence of mast cells and their presence near tumors was first described by Paul Ehrlich many years ago (5). Since then, mast cells have long intrigued the scientific community. However, the data 
Table IV. Characterization of animal response to ketotifen administration: biochemical profile (mean \pm S.E.).

\begin{tabular}{|c|c|c|c|}
\hline Parameter/group & I (MNU) & II (MNU + ketotifen-1) & III (MNU + ketotifen-2) \\
\hline Hematocrit (\%) & $48.50 \pm 1.77^{\mathrm{a}}$ & $48.75 \pm 1.11^{\mathrm{a}}$ & $44.86 \pm 0.86^{\mathrm{a}}$ \\
\hline Albumin (mg/dl) & $29.13 \pm 0.61^{\mathrm{a}}$ & $27.47 \pm 1.34^{\mathrm{a}}$ & $29.60 \pm 0.93^{\mathrm{a}}$ \\
\hline Total protein $(\mathrm{mg} / \mathrm{dl})$ & $58.12 \pm 1.36^{\mathrm{a}}$ & $57.59 \pm 2.58^{\mathrm{a}}$ & $61.11 \pm 1.80^{\mathrm{a}}$ \\
\hline Cholesterol (mg/dl) & $65.03 \pm 6.96^{\mathrm{a}}$ & $55.25 \pm 3.89^{\mathrm{a}}$ & $68.34 \pm 7.37^{\mathrm{a}}$ \\
\hline Glucose $(\mathrm{mg} / \mathrm{dl})$ & $164.90 \pm 7.24^{\mathrm{a}, \mathrm{b}}$ & $152.58 \pm 15.80^{\mathrm{a}}$ & $226.34 \pm 16.29^{b}$ \\
\hline Triglycerides $(\mathrm{mg} / \mathrm{dl})$ & $111.87 \pm 14.63^{\mathrm{a}}$ & $77.33 \pm 7.23^{\mathrm{a}}$ & $116.31 \pm 11.30^{\mathrm{a}}$ \\
\hline Creatinine $(\mathrm{mg} / \mathrm{dl})$ & $0.67 \pm 0.06^{\mathrm{a}}$ & $0.77 \pm 0.13^{\mathrm{a}}$ & $0.58 \pm 0.08^{\mathrm{a}}$ \\
\hline $\operatorname{ALT}(\mathrm{U} / \mathrm{l})$ & $18.53 \pm 2.74^{\mathrm{a}}$ & $15.16 \pm 1.67^{\mathrm{a}}$ & $17.13 \pm 3.24^{\mathrm{a}}$ \\
\hline Creatine kinase (U/1) & $71.67 \pm 11.32^{\mathrm{a}}$ & $147.69 \pm 31.83^{\mathrm{a}}$ & $84.76 \pm 11.74^{\mathrm{a}}$ \\
\hline Lactate dehydrogenase (U/1) & $1312.93 \pm 254.18^{\mathrm{a}}$ & $1878.24 \pm 310.48^{\mathrm{a}}$ & $1164.26 \pm 157.17^{\mathrm{a}}$ \\
\hline Lactate $(\mathrm{mg} / \mathrm{dl})$ & $31.67 \pm 2.60^{\mathrm{a}}$ & $43.38 \pm 4.11^{\mathrm{a}}$ & $31.17 \pm 2.12^{\mathrm{a}}$ \\
\hline $\mathrm{CRP}(\mathrm{AU})$ & $3632.26 \pm 23.35^{\mathrm{a}}$ & $36313.53 \pm 54.04^{\mathrm{a}}$ & $3524.61 \pm 47.34^{\mathrm{a}}$ \\
\hline Urine specific gravity & $1.02 \pm 0.00^{\mathrm{a}}$ & $1.03 \pm 0.00^{\mathrm{a}}$ & $1.02 \pm 0.00^{\mathrm{a}}$ \\
\hline
\end{tabular}

MNU: $N$-Methyl- $N$-nitrosourea. a Statistically different from group III (MNU+ketotifen-2).

Table V. Histological classification of mammary tumors developed by animals from experimental groups that received the carcinogen agent $N$-methyl-N-nitrosourea (MNU).

\begin{tabular}{|c|c|c|c|c|}
\hline \multirow[t]{2}{*}{ Lesions } & & \multicolumn{3}{|c|}{ Number of lesions } \\
\hline & & I (MNU) & II (MNU + ketotifen-1) & III (MNU + ketotifen-2) \\
\hline \multicolumn{5}{|l|}{ Benign } \\
\hline Intraductal papilloma & & 1 & 1 & 5 \\
\hline Tubular adenoma & & 0 & 2 & 3 \\
\hline Fibroadenoma & & 1 & 1 & 1 \\
\hline & Total: & $2^{\mathrm{a}}$ & 4 & 9 \\
\hline \multicolumn{5}{|l|}{ Preneoplastic } \\
\hline Intraductal proliferation & & 0 & 0 & 2 \\
\hline \multicolumn{5}{|l|}{ Malignant } \\
\hline Papillary non-invasive carcinoma & & 14 & 16 & 13 \\
\hline Cribriform non-invasive carcinoma & & $3^{\mathrm{b}, \mathrm{c}}$ & 11 & 12 \\
\hline Papillary invasive carcinoma & & 6 & 6 & 7 \\
\hline Cribriform invasive carcinoma & & 9 & 7 & 4 \\
\hline \multirow[t]{3}{*}{ Comedo invasive carcinoma } & & 1 & 0 & 1 \\
\hline & Total: & 33 & 40 & 37 \\
\hline & Total number of lesions: & 35 & 44 & 48 \\
\hline
\end{tabular}

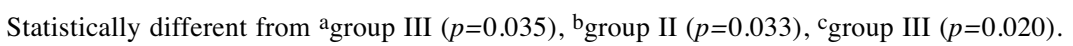

Table VI. Immunohistochemical evaluation of proliferation and apoptosis of mammary tumors developed by animals from experimental groups that received the carcinogen $\mathrm{N}$-methyl-N-nitrosourea $(M N U)$.

\begin{tabular}{lcccc}
\hline Antibody & Parameter & \multicolumn{2}{c}{ Group } \\
\cline { 3 - 5 } & & I (MNU) & II (MNU + ketotifen-1) & III (MNU + ketotifen-2) \\
\hline Ki-67 & Proliferation index (\%) & $8.78 \pm 1.94^{\mathrm{a}}$ & $4.22 \pm 0.77^{\mathrm{b}}$ & $8.08 \pm 1.70^{\mathrm{a}}$ \\
Caspase-3 & Apoptotic index (\%) & $4.16 \pm 0.76$ & $3.14 \pm 0.50$ & $4.08 \pm 0.48$ \\
Caspase-9 & Apoptotic index (\%) & $3.24 \pm 0.53$ & $2.38 \pm 0.37$ & $3.03 \pm 0.52$ \\
\hline
\end{tabular}

aStatistically different from group III (MNU+ketotifen-2) $(\mathrm{p}<0.05)$. 

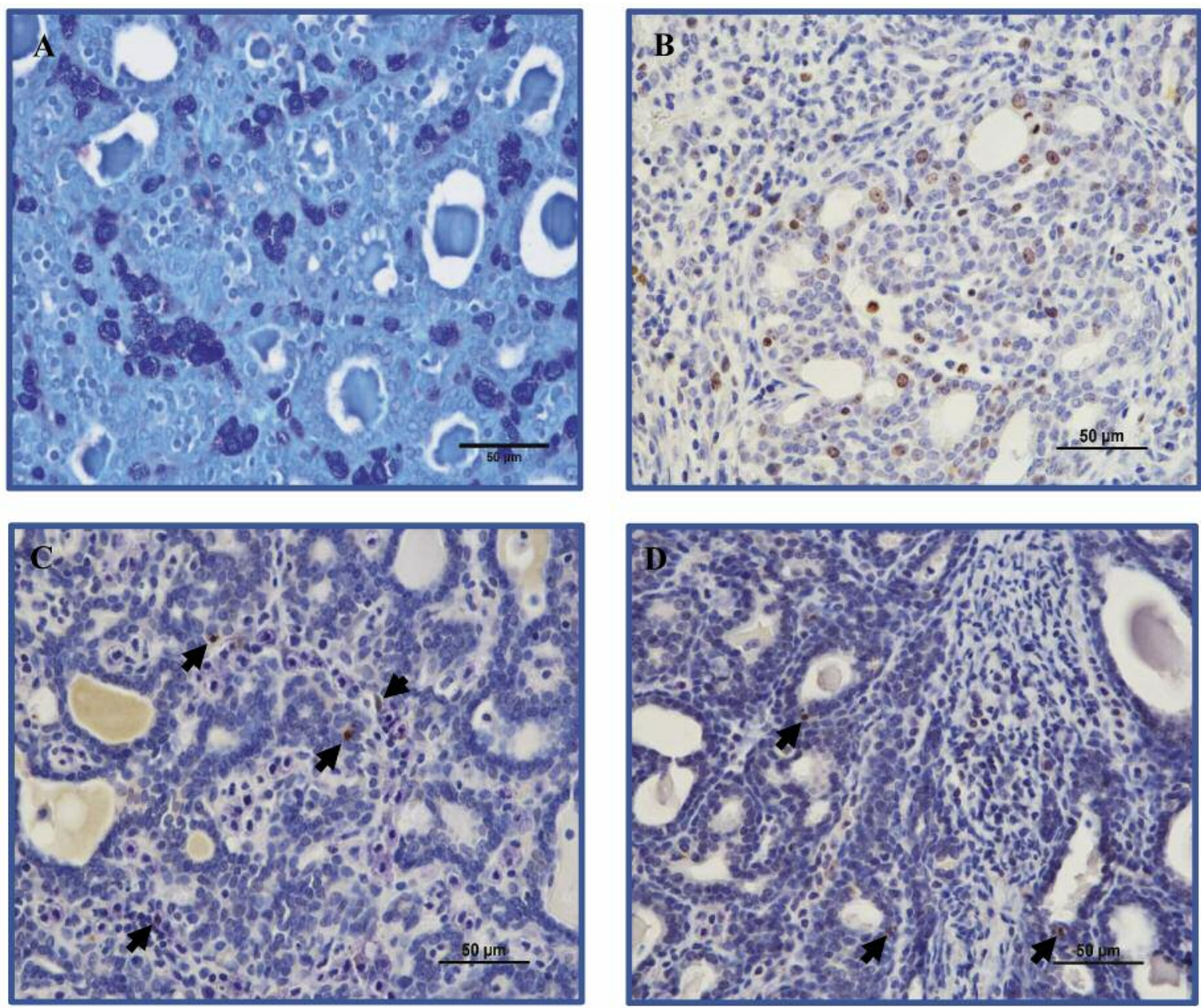

Figure 4. Mast cells stained with toluidine blue appearing purple in color in a papillary carcinoma MNU-induced (A). Immunohistochemical staining for Ki-67 (B), caspase-3 $(C)$ and caspase-9 (D) in a mammary cribriform carcinoma induced by MNU in female rats. Mast cells stained with toluidine blue appearing purple in color in a papillary carcinoma induced by $N$-methyl- $N$-nitrosourea. Immunopositive cells in images stained with caspase- 3 and -9 are indicated by arrows. Magnification of $40 x$ in all images.

on their role have been contradictory and inconclusive, probably due to the different models in which they have been studied. In the present work, we intended not only to evaluate the effects of mast cell inhibition before the beginning of carcinogenesis (preventative approach), but also after the development of mammary tumors (therapeutic approach). In this way, we decided to administer the wellknown and frequently used antihistamine drug ketotifen. This drug was selected not only for its inhibitory action of histamine by the blockage of $\mathrm{H} 1$ receptors, but also because it stabilizes mast cell membrane, avoiding the release of other substances contained in their granules that may act as both pro- and antitumoral agents. In previous work, promising results such as clotting of blood vessels, hypoxia and tumor cells apoptosis were observed after the treatment of mouse models of mammary adenocarcinoma and pancreatic cancer with the mast cell stabilizing drug disodium cromoglycate (cromolyn), even administered after the tumor initiation. However, this mast cell stabilizer drug is a weak inhibitor of human mast cells and is not used in humans (27).

Mammary tumors chemically induced by the carcinogen MNU in female Sprague-Dawley rats have long been used for the study of mammary carcinogenesis (28). In the present study, mammary tumors were successfully induced 8 weeks after MNU administration in animals exposed to this carcinogen. However, conversely to the $100 \%$ incidence previously observed in work performed by our research team using the same model, in the present work a maximum incidence of $89 \%$ was reached. This difference is probably related to the duration of the experimental protocol: in the first study, the animals were sacrificed 35 weeks after MNU 
administration, while in the present one, they were sacrificed 18 weeks after MNU administration $(28,29)$. Although the number of mammary tumors at the end of the experiment was slightly lower in animals from group III that only received the ketotifen after the development of the first mammary tumor, the mean number of mammary tumors per animal was lower in group II, i.e. in animals that received the ketotifen immediately after the MNU administration. Tumors from animals of group II exhibited higher weight and volume when compared with tumors from group III (MNU plus ketotifen-2) $(p>0.05)$, which seems to indicate that the inhibition of mast cell degranulation before tumor development favors tumor growth.

Ketotifen was administered at a dose of $1 \mathrm{mg} / \mathrm{kg}$ per os because it was previously demonstrated as being effective in the reversal of anaphylactic reaction in rats (30) and it had been observed that at low concentration ketotifen inhibits histamine release but the converse occurs at higher concentrations in human conjunctival mast cells (31). Although changes in lipid profile have long been associated with malignancies, as lipids play a key role in maintenance of cell integrity (32), in the present study significant changes were not observed.

Histologically, a higher number of mammary lesions was observed in ketotifen-treated groups (groups II and III) when compared with non-treated group I (MNU). Uniformly among groups, the majority of lesions were classified as malignant. As previously reported, an intense mast cell infiltrate was observed in all rat chemically-induced mammary tumors, mainly in peri-tumoral fibrous tissue rather than in tumor core (33). Similarly to that reported, the mean number of mast cells in all grades of mammary tumors was higher when compared with normal mammary gland (34). Although it was previously described that as the severity of mammary tumors increased the mast cell count decreased, in the present work it was observed that the group that exhibited the highest number of malignant mammary lesions also exhibited the highest mean number of mast cells (group II, MNU plus ketotifen-1) (35). Similarly to previous observation in a study of rat intestine and mesenterium (ketotifen injected i.v.), where it was observed that ketotifen did not reduce the number of mast cells $(36,37)$, in the present work the ketotifen inhibited mast cell degranulation (lower histamine concentration) but did not reduce the number of mast cells. Although the mast cells number was not reduced, their activity was inhibited.

$\mathrm{Ki}-67$ is involved in cellular proliferation, being considered an important proliferative marker in mammary cancer (38). Caspases-3 and -9 act as effector and initiator, respectively, in both extrinsic and intrinsic pathways of apoptosis that culminate with the degradation of cellular structures and formation of apoptotic bodies (39). As a higher immunoexpression of Ki-67 (proliferative index) was observed in groups I (MNU) and III (MNU + ketotifen-2) when compared with group II (MNU plus ketotifen-1), a lower immunoexpression of caspase-3 and -9 (apoptotic index) was expected in these groups. Surprisingly, both proliferative and apoptotic indices were lower in group II (MNU plus ketotifen1) where mast cell degranulation was inhibited before tumor development. These data suggest that the inhibition of mast cell degranulation may inhibit or at least reduce the proliferation of mammary tumors, having a positive effect for the host.

\section{Conclusion}

As far as we are aware of, this study was the first to evaluate the effects of mast cell degranulation inhibition on the model of chemically-induced mammary cancer in female SpragueDawley rats. The results seem to indicate that the inhibition of mast cell degranulation did not change tumor progression (number of mammary tumors and lesions). The main positive effect seems to be the reduction of tumor proliferation (lower proliferative index) when mast cell degranulation was inhibited before tumor development.

\section{Conflicts of Interest}

None to declare.

\section{Acknowledgements}

This work was supported by European Investment Funds by FEDER/COMPETE/POCI - Operational Competitiveness and Internationalization Program, under the project POCI-01-0145FEDER-006958 and the project POCI-01-0145-FEDER-016728, and Portuguese Science and Technology Foundation (FCT), under the project UID/AGR/04033/2013, the project PTDC/DES/ $114122 / 2009$, the project PTDC/DTP-DES/6077/2014, and postgraduation grant SFRH/BD/102099/2014.

\section{References}

1 Zudaire E, Martinez A, Garayoa M, Pio R, Kaur G, Woolhiser MR, Metcalfe DD, Hook WA, Siraganian RP, Guise TA, Chirgwin JM and Cuttitta F: Adrenomedullin is a cross-talk molecule that regulates tumor and mast cell function during human carcinogenesis. Am J Pathol 168: 280-291, 2006.

2 Kamal R, Dahiya P, Palaskar S and Shetty VP: Comparative analysis of mast cell count in normal oral mucosa and oral pyogenic granuloma. J Clin Exp Dent 3: 1-4, 2011.

3 Ankle MR: Mast cells are increased in oral leukoplakia, oral submucous fibrosis, oral lichen planus and oral squamous cell carcinoma. J Oral Maxillofac Pathol 11: 18-22, 2008.

4 Hill PB and Martin RJ: A review of mast cell biology. Vet Dermatol 9: 145-166, 1998.

5 Ehrlich P: Beiträge zur Theorie und Praxis der Histologischen Färbung, 1878.

6 Yong LCJ: The mast cell: origin, morphology, distribution, and function. Exp Toxicol Pathol 49: 409-424, 1997. 
7 Blackwood L, Murphy S, Buracco P, De Vos JP, De FornelThibaud P, Hirschberger J, Kessler M, Pastor J, Ponce F, SavaryBataille K and Argyle DJ: European consensus document on mast cell tumours in dogs and cats. Vet Comp Oncol 10: e1-e29, 2012.

8 de Souza DA, Toso VD, Campos MRD, Lara VS, Oliver C and Jamur MC: Expression of mast cell proteases correlates with mast cell maturation and angiogenesis during tumor progression. PLoS One 7: e40790, 2012.

9 Ganapaty S, Chandrashekhar VM and Narsu ML: Evaluation of anti-allergic activity of gossypin and suramin in mast cellmediated allergy model. Indian J Biochem Biophys 47: 90-95, 2010

10 Wang X, Ruan Y and Wu Z: Studies of mast cells-mediated cytotoxicity to hepatoma cells in vitro. Zhonghua Zo Zazhi 18: 276-278, 1996.

11 Ozdemir O: Can chymase-positive mast cells play a role in the progression of gastric cancer via angiogenesis? J Surg Oncol 94: 260-262, 2006.

12 Yano H, Kinuta M, Tateishi H, Matsui S, Monden T, Okamura $\mathrm{J}$, Sakai $\mathrm{M}$ and Okamoto S: Mast cell infiltration around gastric cancer cells correlates with tumor angiogenesis and metastasis. Gastric Cancer 2: 26-32, 1999.

13 Theoharides TC and Conti P: Mast cells: the Jekyl and Hyde of tumor growth. Trends Immunol 25: 235-241, 2004.

14 Flynn EA, Schwartz JL and Shklar G: Sequential mast-cell infiltration and degranulation during experimental carcinogenesis. J Cancer Res Clin Oncol 117: 115-122, 1991.

15 Bowrey PF, King J, Magarey C, Schwartz P, Marr P, Bolton E and Morris DL: Histamine, mast cells and tumour cell proliferation in breast cancer: Does preoperative cimetidine administration have an effect? Br J Cancer 82: 167-170, 2000.

16 Elpek GO, Gelen T, Aksoy NH, Erdogan A, Dertsiz L, Demircan $\mathrm{A}$ and Keles N: The prognostic relevance of angiogenesis and mast cells in squamous cell carcinoma of the oesophagus. J Clin Pathol 54: 940-944, 2001.

17 Ishikawa T, Takechi K, Rahman A, Ago J, Matsumoto N, Murakami A and Kamei C: Influences of histamine H-1 receptor antagonists on maximal electroshock seizure in infant rats. Biol Pharm Bull 30: 477-480, 2007.

18 Brockman H, Graff G, Spellman J and Yanni J: A comparison of the effects of olopatadine and ketotifen on model membranes. Acta Ophthalmol Scand 78: 10-15, 2000.

19 Kalesnikoff J and Galli SJ: New developments in mast cell biology. Nat Immunol 9: 1215-1223, 2008.

20 World Health Organization, World Cancer Report 2014, World Health Organization, Geneva, Switzerland, 2014.

21 Faustino-Rocha A, Oliveira PA, Pinho-Oliveira J, TeixeiraGuedes C, Soares-Maia R, da Costa RG, Colaço B, Pires MJ, Colaço J, Ferreira R and Ginja M: Estimation of rat mammary tumor volume using caliper and ultrasonography measurements. Lab Anim 42: 217-24, 2013.

22 Faustino-Rocha AI, Silva A, Gabriel J, Reixeira-Guedes C, Lopes C, Gil da Costa R, Gama A, Ferreira R, Oliveira P and Ginja M: Ultrasonographic, thermographic and histologic evaluation of MNU-induced mammary tumors in female Sprague-Dawley rats. Biomed Pharmacother 67: 771-776, 2013.

23 Forbes D, Blom H, Kostomitsopulos N, Moore G and Perretta G: Euroguide: on the accommodation and care of animals used for experimental and other scientific purposes. London, Federation of European Laboratory Animal Science Associations, 2007.
24 Russo J and Russo IH: Atlas and histologic classification of tumors of the rat mammary gland. J Mammary Gland Biol Neoplasia 5: 187-200, 2000.

25 Lavalle GE, Bertagnolli AC, Tavares WLF, Ferreira M and Cassali GD: Mast cells and angiogenesis in canine mammary tumor. Arq Bras Med Veterinaria Zootec 62: 1348-1351, 2010.

26 WHO: Cancer - Fact sheet no. 297. World Health Organization, Geneva, Switzerland, 2015.

27 Ribatti D and Crivellato E: Mast cells, angiogenesis and cancer. In: Mast Cell Biology: Contemporary and Emerging Topics. Gilfillan AM and Metcalfe DD (eds.). New York, Springer, pp. 270-288, 2011.

28 Faustino-Rocha AI, Ferreira R, Oliveira PA, Gama A and Ginja M: N-Methyl-N-nitrosourea as a mammary carcinogenic agent. Tumor Biol 36: 9095-9117, 2015.

29 Faustino-Rocha A, Gama A, Oliveira PA, Alvarado A, Neuparth MJ, Ferreira R and Ginja M: Effects of lifelong exercise training on mammary tumorigenesis induced by MNU in female SpragueDawley rats. Clin Exp Med, 2016. [Epub ahead of print]

30 Craps LP: Current views on the mechanism of action of ketotifen and theri therapeutic implications. Solunum 8: 78, 1983.

31 Yanni JM, Stephens DJ, Miller ST, Weimer LK, Graff G, Parnell D, Lang LS, Spellman JM, Brady MT and Gamache DA: The in vitro and in vivo ocular pharmacology of olopatadine (AL4943A), an effective anti-allergic/antihistaminic agent. J Ocul Pharmacol Ther 12: 389-400, 1996.

32 Gupta $S$ and Gupta $S$ : Alterations in serum lipid profile patterns in oral cancer and oral precancerous lesions and conditions - a clinical study. Indian J Dent Res 2: 2-6, 2011.

33 Strum JM, Lewko WM and Kidwell WR: Structural alterations within $\mathrm{N}$-nitrosomethylurea-induced mammary-tumors after in vivo treatment with cis-hydroxyproline. Lab Investig 45: 347-354, 1981.

34 Samoszuk M, Kanakubo E and Chan JK: Degranulating mast cells in fibrotic regions of human tumors and evidence that mast cell heparin interferes with the growth of tumor cells through a mechanism involving fibroblasts. BMC Cancer 5: 121, 2005.

35 Rajendran R, Radhakrishnan NS and Kartha CC: Light and electron microscopic studies on oral submucous fibrosis. J Indian Dent Assoc 64: 157-161, 1993.

36 Kimura M, Mitani H, Bandoh T, Totsuka T and Hayashi S: Mast cell degranulation in rat mesenteric venule: Effects of L-name, methylene blue and ketotifen. Pharmacol Res 39: 397-402, 1999.

37 Hei ZQ, Gan XL, Huang PJ, Wei J, Shen N and Gao WL: Influence of ketotifen, cromolyn sodium, and compound 48/80 on the survival rates after intestinal ischemia reperfusion injury in rats. BMC Gastroenterol 8: 42, 2008.

38 Mrklic I, Capkun V, Pogorelic Z and Tomic S: Prognostic value of Ki-67 proliferating index in triple-negative breast carcinomas. Pathol Res Pract 209: 296-301, 2013.

39 Ekoff M and Nilsson G: Mast cell apoptosis and survival. J Ocul Pharmacol Ther 12: 389-400, 1996. 